\title{
On some special classes of Gronwall lemmas
}

\section{ANTON S. MUREŞAN}

\section{ABSTRACT.}

Problem 9 in [Rus, I. A., Gronwall lemmas: ten open problems, Scientiae Math. Jpn., 70 (2009), No. 2, 221-228] is the following: Give new concrete and abstract Gronwall lemmas. The aim of this paper is to give and study some special classes of Gronwall lemmas.

Department OF STATistics, Forecasts AND MATHEMATiCS

"BABEŞ-BOLYAI" UNIVERSITY

FACULTY OF ECONOMIC SCIENCES AND BUSINESS ADMINISTRATION

T. MiHALI 58-60, 400591 CLUj-NAPOCA, ROMANIA

E-mail address: anton.muresandecon.ubbcluj.ro

Received: 30.10.2011; In revised form: 03.09.2012; Accepted: 15.10.2012

2010 Mathematics Subject Classification. 47H10, 54H25.

Key words and phrases. Fixed point, lower fixed point, upper fixed point, Gronwall lemma, weakly Picard operator, differential inequality, integral inequality, operatorial inequality. 